\title{
The aesthetic terrain of settler colonialism: Katherine Mansfield and Anton Chekhov's natives
}

\section{Rebecca Ruth Gould}

To cite this article: Rebecca Ruth Gould (2018): The aesthetic terrain of settler colonialism: Katherine Mansfield and Anton Chekhov's natives, Journal of Postcolonial Writing, DOI: 10.1080/17449855.2018.1511242

To link to this article: https://doi.org/10.1080/17449855.2018.1511242

册 Published online: 04 Oct 2018.

Submit your article to this journal $\pi$

Џ Article views: 1

View Crossmark data ¿ 


\title{
The aesthetic terrain of settler colonialism: Katherine Mansfield and Anton Chekhov's natives
}

\author{
Rebecca Ruth Gould \\ College of Arts and Law, University of Birmingham, Birmingham, UK
}

\begin{abstract}
While Anton Chekhov's influence on Katherine Mansfield is widely acknowledged, the two writers' settler colonial aesthetics have not been brought into systematic comparison. Yet Chekhov's chronicle of Sakhalin Island in the Russian Far East parallels in important ways Mansfield's near-contemporaneous account of colonial life in New Zealand. Both writers are concerned with a specific variant of the colonial situation: settler colonialism, which prioritizes appropriation of land over the governance of peoples. This article considers the aesthetic strategies each writer develops for capturing that milieu within the framework of the settler colonial aesthetics that has guided much anthropological engagement with endangered peoples.
\end{abstract}

\section{KEYWORDS}

Settler colonialism; Sakhalin; New Zealand; Siberia; Maori; Gilyak; Russian Empire

Indigenous peoples' $[\ldots]$ survival $[\ldots]$

will [ ... ] contradict the most fundamental characteristic

of what being 'indigenous' (in the eyes of the settler) is

all about: they will not go away.

\section{-Lorenzo Veracini, 'Introducing Settler colonial Studies'}

In 1907, a 19-year-old Katherine Mansfield embarked on a 3-week journey through New Zealand's central North Island. Her destination was the Ureweras, a remote region in the north island of New Zealand, where she compiled the notes that were later to be reworked in her stories. It was to be her final journey through her home country. Mansfield left New Zealand the following year to resume her life in England, and never returned home. The notebook Mansfield kept of that journey mixes travel notes and reportage with details about the New Zealand landscape and the Maori language. In this notebook, Mansfield pioneered the new "technique of observation and reportage" (Gordon 1993, 20), ${ }^{1}$ that is also evident in the following description of a native woman:

A young Maori girl - climbs slowly up the hill - she does not see me - I do not move - she reaches a little knoll - and suddenly sits down - native fashion - her legs crossed her under her hands clasped in her lap - She is dressed in a blue skirt \& white soft blouse - Round her neck is a piece of twisted flax \& a long piece of greenstone - is suspended from it - Her black hair is twisted softly at the neck - She wears long white \& red bone earrings. She is very young -

CONTACT Rebecca Ruth Gould r.r.gould@bham.ac.uk $@$ College of Arts and Law, University of Birmingham, Birmingham, UK

๑) 2018 Informa UK Limited, trading as Taylor \& Francis Group 
she has [five illegible words deleted]. She sits silent - utterly motionless - her head thrown back - All the lines of her face are passionate violent - crudely savage - but in her lifted eyes struggles a tragic, illimitable Peace -

The sky changes - softens - the lake is all grey mist - the island in heavy shadow - silence broods among the trees - . - The girl does not move. But ahead far far away - very faint and sweet and beautiful - a star wakes in the sky -

She is the very incarnation of evening - and lo - the first star - shines in her eyes. (Mansfield 2015, 107) ${ }^{2}$

The excisions and punctuation attest to the care with which Mansfield composed this literary sketch, as if it were a draft for a more polished work. As she generates broken syntax suffused with jarring images, Mansfield simultaneously exoticizes and humanizes the Maori girl. Viewed from afar, the native girl does not see the author; the distance between viewer and viewed opens up a space for closer observation. The girl is also memorialized as if in a prelude to her disappearance. Mansfield recognizes the dignity and beauty of the girl even as she incorporates her into a landscape undergoing deforestation in order to clear a path for white settlers. The girl merges with the cosmos as "the first star - shines in her eyes". The destruction of the Maori way of life is made to appear imminent, terrifying and sublime all in the same words. Unable to stop the impending destruction, the writer turns it into an object of aesthetic reflection.

Only a decade earlier, the Russian writer Anton Chekhov encountered a similar situation among the indigenous people of Sakhalin, an island in the Pacific Ocean, just north of Japan and marking the north-easternmost edge of the Russian Empire. Since the 1860s, Sakhalin had also become "Russia's grimmest penal colony" (Rayfield 1997, 215). Convicts were sent here from central Russia after the authorities had determined that they were beyond rehabilitation. Although other Russian writers subsequently travelled to Sakhalin, and used the difficult conditions there to launch broader arguments against the Russian penal system, Chekhov was the first to pursue this line of critique. He was also the only writer of the time to include an ethnography of indigenous peoples, particularly the Gilyak (who call themselves the Nivkh), in his discussion of Sakhalin as a penal colony. Other progressive writers, such as Vlas Doroshevich (1865-1922), who explored Sakhalin (Doroshevich [1905] 2009), used the example of this penal colony primarily to denounce the treatment of Russian prisoners, rather than to expose the settler colonial process that was gradually overtaking the region.

The Gilyak were facing annihilation because of Russification policies and the spread of the diseases introduced by Russian settlers. Images from the time reinforce the sense of their alterity (Figures 1 and 2). Chekhov's account of the Gilyak gently normalizes (while forecasting) their eventual extinction. He writes:

The Gilyak belong neither to a Mongoloid nor to a Tungic stock, but rather to an unknown tribe that was once perhaps magnificent and which ruled over all of Asia but which is now living out its last era on a small patch of land as a not very numerous, yet still beautiful and brave, people. (Chekhov 2010, 130) 

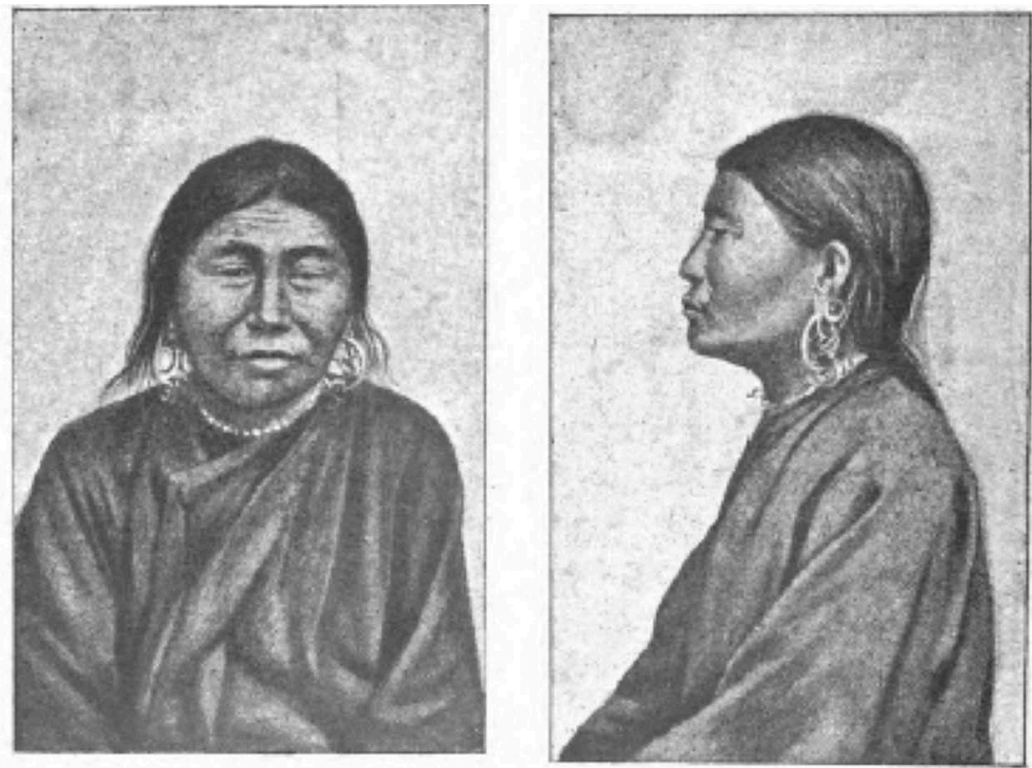

Figure 1. Sketch of a Gilyak woman (Labbé 1903, 216).

As if prognosticating their eventual disappearance from the earth, Chekhov notes that

as a result of their unusual friendliness and mobility, the Gilyak have mixed with all of their neighbours, making it impossible now to encounter a pur sang [pure-blooded] Gilyak, who is not in some way related to a Mongol, Tungic, or Ain people. (130)

From Chekhov's perspective, the Gilyak's racial impurity made the prospect of their eventual extinction less tragic. Here and elsewhere, Chekhov participates in a tradition of salvage anthropology that "constructed a canon of authenticity [ ... ] to filter modern adaptations from culture in order to discover a supposedly 'authentic' culture that had existed in the past" and which regarded divergence from this constructed authenticity as a sign of impurity (Nurse 2011,63). Figures 3 and 4 reflect this impression of the Gilyaks as representatives of a vanishing form of life. Because the Gilyak were seen to be on the brink of disappearance, they were perpetually in need of the ethnographer who could reconstruct their ways of life for a colonial readership.

Contrary to Chekhov's predictions, the Gilyak survived, albeit in small numbers. The 2010 Russian estimated their combined population at $5000{ }^{3}$ They were the subject of an important Soviet ethnography by the Jewish anthropologist Lev Shternberg, which was eventually published by the American Museum of Natural History (see Shternberg [1933] 1999). As Chekhov predicts the Gilyak's disappearance from the earth, he renders their ways of life and culture with the same painstaking detail he lavishes on his literary characters. In anecdote after anecdote, Chekhov dwells on the Gilyaks' sense of humour and their aversion to lying. In his words, the Gilyak "lie only when they are trading or conversing with suspicious individuals or with those who are, in their opinion, dangerous" (Chekhov 2010, 134). At the same time, Chekhov goes well beyond 


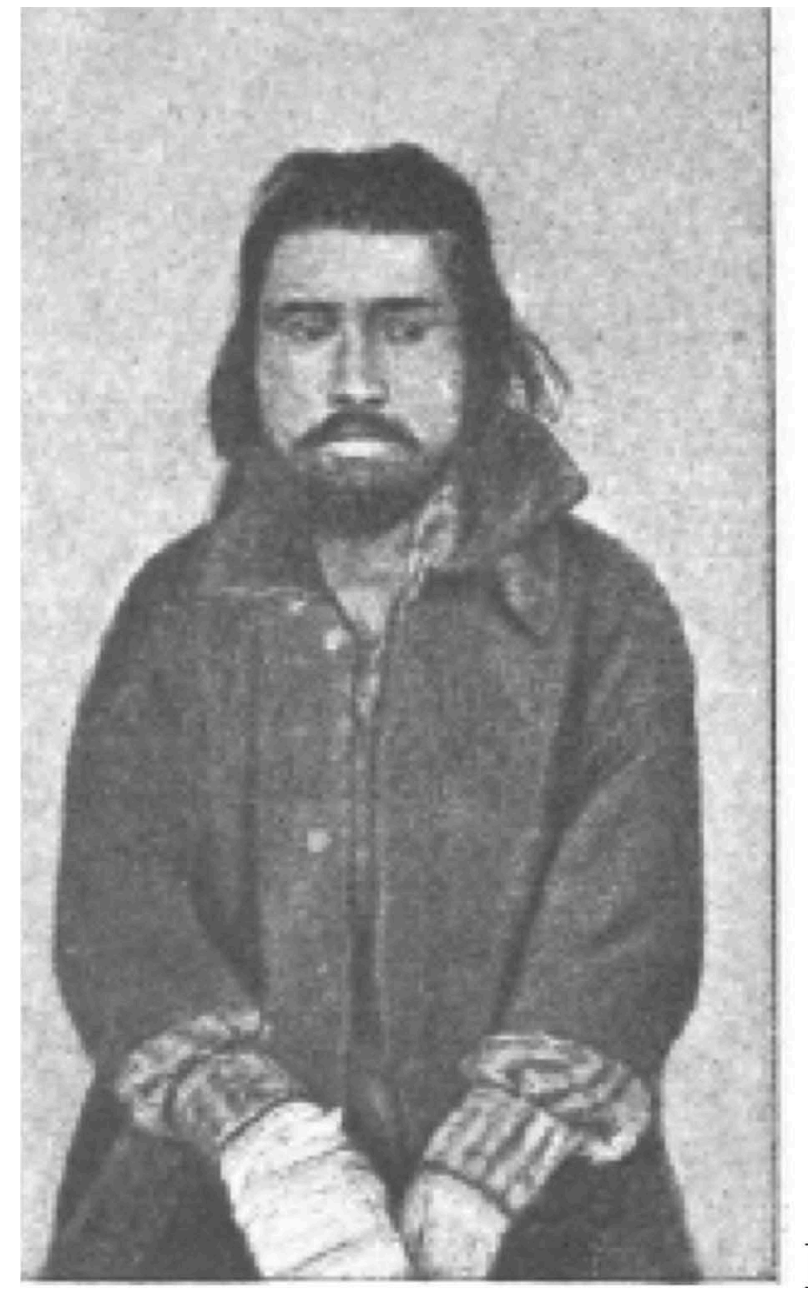

Figure 2. Sketch of a Gilyak man (Labbé 1903, 207).

this type of ethnographic observation. Albeit briefly, he enters into the lifeworld of this indigenous people in ways that no writer prior to him had done.

One example is a scene that follows immediately after an extended ethnographic exegesis of the Gilyak, in which Chekhov becomes a character in his own narrative. He recounts being asked about his profession by a group of inquisitive Gilyaks. After telling them that he is a writer (pisar'), he is asked about his salary. Chekhov informs the Gilyaks that he earned 3000 roubles a month. "One had to see what an unpleasant, even sickness-inducing, impression my answer made on them", Chekhov (2010, 134) recounts. The Gilyak interlocutors writhe on the ground in pain, while their faces radiate despair. What caused this extreme reaction? Ever the skilful storyteller, Chekhov does not say directly. Instead, he lets his characters tell the story. "Why did you say such a thing?" the Gilyak says, citing the much lower local rate. Chekhov then explains why such a salary is necessary for a traveller like himself. While the Gilyak are initially scandalized by the high figure, Chekhov manages to persuade them in the end that his 


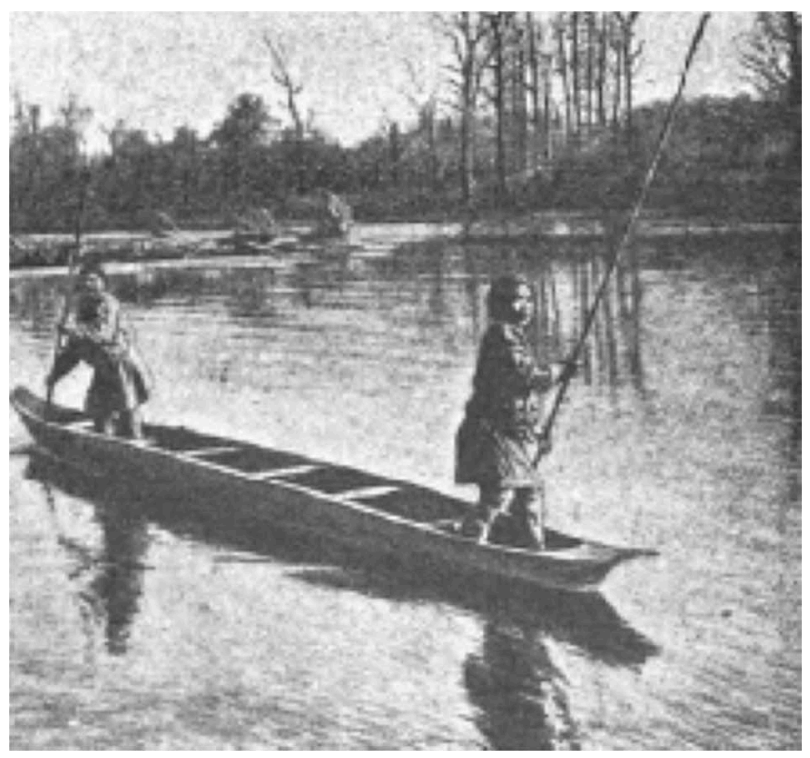

Figure 3. A Gilyak canoe (Labbé 1903, 226).

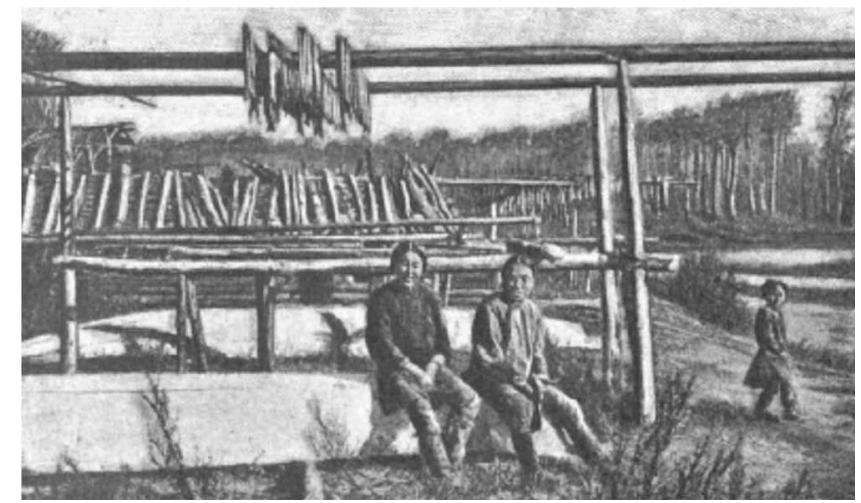

Figure 4. Gilyak girls fishing (Labbé 1903, 215).

"compensation" is reasonable. This incident is illuminating not only for its content, but for its understated irony, reminiscent of a Chekhovian short story.

Distinctively, yet drawing on cognate discourses, Mansfield and Chekhov contributed to the merger of a new genre of salvage ethnography with an older tradition of travel writing (Chekhov in fact subtitled his book "Travel Notes"). As a genre, salvage ethnography reconstructs on paper an indigenous way of life in anticipation of its disappearance from the world. The modes of affective representation specific to this type of engagement range from lament to eulogy to nostalgia; they share a perception of the subject of representation as under threat of extinction, and a commitment to aestheticizing the process of annihilation. The aims and methods deployed by texts within this genre that gives verbal shape to vanishing forms of life are too diverse to collapse into a single framework, but certain themes and techniques can be identified. 
They relate to, but do not wholly encompass, the aesthetic techniques of the colonial and postcolonial literary traditions that have dominated this field. Critically, salvage ethnography is foundational to an imperial practice that holds, as one settler colonialist wrote in 1838, that "the wiser course would be, to let the native race gradually retire before the settlers, and ultimately become extinct" ("Colonisation in South Australia and New Zealand", 1838, 258).

Ethnographic travel writing often articulates a settler colonial take on racial difference by juxtaposing the settlers to the indigenous population, sometimes elevating the latter, and on other occasions denigrating them. Briefly, the settler colonial project can be defined as one that relates to the original inhabitants as objects destined for (gradual) extinction and which naturalizes the colonizer's relationship to the territory being colonized, even while (sometimes) lamenting the process through which this colonization takes place (Veracini 2011a, 2011b). Colonialism in the classical imperial sense aims to govern an often unruly or resistant populace; settler colonialism, by contrast, aims at effecting this population's annihilation, at least to the extent that the new territorial claims can be naturalized. Settler colonialism justifies itself by making a claim to land rather than through civilizational hierarchies, as is the case with imperial colonialism (as famously analysed in Said [1978, 1993]). Mansfield's and Chekhov's engagements with and subversions of existing settler colonial discourses are the two points along the settler colonial discursive continuum with which this article is concerned. I engage here with these two authors' works with the aim of better understanding the aesthetic dimensions of settler colonialism as a political project, and in order to trace how aesthetic perception transforms structures of domination into spaces of critique.

Chekhov studies tends to situate this author within a European literary canon; only a few scholars have engaged with him from a postcolonial perspective (Lantz 2013; Dutt 2013), or attended to his critique of empire (Grant 1995, 46-48; 1997; Beer 2016). By contrast, Mansfield scholars have explored how her fiction and travel writings engage the borderlands of empire in multiple monographs, edited collections, and special journal issues (most notably Wilson, Kimber, and Correa 2013). Yet long before the postcolonial turn within Mansfield studies, indigenous writers engaged with Mansfield's representation of the settler colonial encounter. Most famously, the New Zealand indigenous writer Witi Ihimaera (b. 1944) staged a dialogue with Mansfield in his collection Dear Miss Mansfield (Ihimaera 1989). Scholars such as Janet Wilson (2013), Mark Williams (2000), Bridget Orr (1995), Ian Gordon (1993), Elleke Boehmer (2011) and Saikat Majumdar (2013, 71-99) have subsequently considered how Mansfield critically reframed literary modernism by infusing this metropolitan literary movement with colonial themes and experience. Moving beyond the Anglophone construction of a writer with an at best attenuated relationship to her colonial roots, this article engages with the ongoing postcolonial rereading of Mansfield by inquiring into how her representation of New Zealand's native inhabitants illuminates settler coloniality's aesthetic forms. I pursue this goal by comparing Mansfield's Urewera Notebook with the ethnographic narrative of Sakhalin by her Russian predecessor in the art of the short story, Anton Chekhov. While Chekhov's own literary influences provide a basis for treating him as a European writer, the ethnographic engagement with Sakhalin that consumed a large portion of his brief life enables us to read his texts in a more global 
trans-imperial context. ${ }^{4}$ Chekhov's ethnography also enables us to engage with Russophone literature as a literature of empire, and to take account of how the nonRussian subjects of Russian literary representation might have described the process of settler coloniality. ${ }^{5}$

Critics of postcolonial studies have long taken the field to task for homogenizing different modalities of colonialism under a single heading. It has been argued that the diverse ways in which colonial rule has been experienced across the globe cannot be theorized within the framework of a single unit of analysis. For these critics, postcolonial theory fails to cohere as a method of inquiry (see Ahmad 1992). The logics that underwrite each and every colonial situation, so this argument runs, are too disaggregated, and too distinct, to generate universalizable results. Yet a case can also be made for a more comprehensive and systematic analysis attuned to the aesthetic logic of the colony as political form. As Rodinson ([1968] 1973) argued in his analysis of Israel as a settler colony, while "there is no such thing as colonialism and imperialism" in the singular, "there is a series of social phenomena in which numerous analogies with one another can be found, but also infinite nuances, and which have come to be referred to with labels" (36). ${ }^{6}$

Alongside the argument against generalizing the colonial condition, there has been an effort to disambiguate postcoloniality geographically. The advent of settler colonial studies, which can be dated to the publication of Patrick Wolfe's (1999) seminal study, Settler Colonialism, complicates postcolonial theory's homogenization of historical, cultural and geographic difference, while offering a paradigm for studying forms of colonial rule that reject the paradigm of exogenous domination from afar. While Wolfe offers a variation on colonial domination through his analysis of settler colonialism, pioneering voices within this emergent field insist that "colonialism is not settler colonialism" because "colonisers and settler colonisers want essentially different things" (Veracini 2011a, 1). The texts under discussion here suggest that, while the postcolonial paradigm is premised on a model of colonial rule that fits the British and French empires, whereby a colonial regime is eventually superseded by a postcolonial elite, the anti-colonial, rather than the postcolonial model, best plots the trajectory of settler coloniality. At the same time, settler colonies, and settler colonial literature, maintain close contact with imperial colonial audiences. Such readerly dynamics are relevant for the study of settler colonial literature insofar as it means that, even if settler colonial aesthetics diverge from the aesthetics of imperial colonial representation, the two audiences often converge. Chekhov's audience was comprised of readers across the Russian Empire, who would have related to the Gilyaks not as to a people they hoped to replace, but rather as an exotic tribe awaiting a presumably divinely ordained extinction. The colonial encounter would have looked quite different from the vantage point of the Russian convicts who were residing on the island alongside the indigenous population. As with Chekhov, so with Mansfield: writing for an audience that spanned the British Empire, she addressed multiple colonial readerships, including imperial British subjects and settler colonial inhabitants of New Zealand.

According to Wolfe (2006), "territoriality is settler colonialism's specific, irreducible element" that sets it apart from other forms of violent racially structured governance (388). ${ }^{7}$ Wolfe defines settler colonialism as "an inclusive, land-centred project that coordinates a comprehensive range of agencies, from the metropolitan centre to the 
frontier encampment, with a view to eliminating Indigenous societies" (393). Veracini (2011a) elaborates on Wolfe's pioneering work in the introductory essay to the inaugural issue of Settler Colonial Studies, where he argues for understanding "colonialism and settler colonialism [ ... ] in their dialectical relation" rather than as variations on each other or subordinate categories within a broader continuum (1). Veracini further argues that the colonial encounter is mirrored by a settler colonial "non-encounter" that is "premised on a foundational disavowal" of the indigenous other $(2011 \mathrm{~b}, 5)$.

Amid their provocative analysis of social processes, these social scientists leave unexplored the aesthetic dimensions of the settler colonial encounter. Just as the imperial encounter has its own specific forms of representation, and a repertoire of genres and discourses specific to its logic of power, so too is the settler colonial encounter characterized by the distinctive aesthetic forms theorized in ShalhoubKevorkian (2016) and Glissant (1997). This article is a preliminary effort towards identifying those aspects of settler colonial aesthetics that resist, complicate and hinder settler colonial dominance. Such literary excavations demonstrate that, while few canonical modernist texts entirely avoid complicity with settler colonial discourses when they engage with indigenous populations, the aesthetics borne from this mode of colonization can also accommodate critiques and subversions of their dominant political projects.

Where do Mansfield and her New Zealand subjects fit into the postcolonial turn? What does Chekhov's rendering of Sakhalin have to do with the critique of empire? Although Mansfield's stories are increasingly incorporated into a postcolonial canon, her specific take on the settler colonial condition remains at the margins of her reception. Aretoulakis (2013) has highlighted some key aspects of Mansfield's treatment of the colonial situation: her interest in liminal situations, her cultivation of "third spaces" that resist dichotomies of colonizer/colonized, and her interest in death scenes as a means of challenging the hegemonic logic of colonial power. In this last respect in particular, Mansfield joins with Chekhov: latent parallels in their oeuvres between the mortality made evident by their tuberculosis, and the species extinction that the settler colonial condition forced them to contemplate, bring politics into close relation with their own mortality. Chekhov embarked on the treacherous 11-week journey to Sakhalin in full knowledge that it would hasten his death. Similarly, Mansfield's depiction of the indigenous peoples of the Urewera is shot through with the shadow of their mortality. Affectively, this experience takes the form of jarring brevity, including the stark juxtapositions in describing the Maori girl (in some ways a mirror for herself) in the passage cited above. While Mansfield's preoccupation with mortality received fuller expression in stories such as her 1922 "The Garden Party", the Urewera notebook serves as a prelude of what was to come. As they resigned themselves to their imminent deaths, both writers pioneered new ways of registering the gradual annihilation of indigenous peoples.

Like New Zealand, Sakhalin is located on the edge of a vast imperial geography. A comparison between Mansfield's treatment of the Maori, whom she encountered shortly before sailing to England in 1908, never to return home, and Chekhov's account of Sakhalin, a penal colony located so deep in the Russian Far East that Chekhov described it as the end of the earth [konets sveta] (quoted in Popkin 1992, 36) is therefore long overdue. As they probe imperial frontiers, both authors offer new ways of understanding settler colonialism, within and in contrast to imperial coloniality. 
There are many reasons to bring these two bodies of work into comparison. Arguably the most persuasive is Mansfield's selection of Chekhov as her master in the short story genre. Although scholars have tried to map a precise genealogy of Chekhov's influence on her work, according to Mansfield herself, Chekhov's most profound influence was less on her writerly craft than on her way of life. Mansfield's debt to Chekhov is evident in a comparison she made of his empathetic gifts with those of Dostoevsky, who always had a social network to support him when he fell into debt or illness. Once, during a crisis, Mansfield wrote:

Chekhov would understand: Dostoievsky wouldn't. Because he's never been in the same situation. He's been poor and ill and worried but, enfin, the wife has been there to sell her petticoat, or there has been a neighbour. He wouldn't be alone. But Tchekov has known just exactly this that I know. I discover it in his work often. $(1951,293)$

Chekhov was a model for Mansfield in more than the realm of art. Like her, he died young, and of the very same disease: tuberculosis. Although his art did not dwell on illness, Chekhov's experience with tuberculosis clearly shaped his writing trajectory, as it did Mansfield's. Chekhov was more to Mansfield than a masterful writer; he was a kindred spirit, to whom she appealed when overwhelmed by the pain and fear of dying alone. A note dated July 5, 1918 from Mansfield's Journal reads: “Tchekov! why are you dead? Why can't I talk to you, in a big darkish room, at late evening. [ ... ] I'd like to write a series of Heavens: that would be one" (1946, 93). Comparing Mansfield's and Chekhov's aesthetics, therefore, means studying a way of living and a way of dying, for both reveal the settler colonial condition. A more comprehensive exploration of the role of settler colonialism in shaping these writers' aesthetics would also consider how two creative artists who died from tuberculosis at the ages of 35 and 44 respectively negotiated the relation between art and life as they confronted their imminent deaths, and how their mortality affected their artistic praxis.

While there are obvious historical and aesthetic parallels between Mansfield's and Chekhov's writings on settler colonialism, there are equally salient differences. First and foremost, one must consider questions of audience. Whereas Chekhov worked on his Sakhalin book for many years, Mansfield's sketches of indigenous New Zealand are concentrated into a single notebook that was not intended for publication, although she drew on it extensively as a source for her stories. Whereas Mansfield admired the pure artistry of Chekhov's short stories, in his Sakhalin book, Chekhov moved beyond fiction and aimed to directly influence political life. In contrast to Chekhov's published book on Sakhalin and the Russian penal system, Mansfield's only agenda was the cultivation of her artistic gifts. Her reflections on settler colonialism were not intended to affect public debate. By contrast, in his nonfictional writings on Sakhalin, Chekhov sought to stimulate within the Russian body politic a movement for reforming the Russian penal system. Like other writers of his time, Chekhov was less troubled by the colonization of the Gilyak than he was by the impact of the penal system on the Russian convicts in Sakhalin, who were forced "to drag themselves in chains across tens of thousands of kilometers in freezing conditions, infected [ ... ] with syphilis, and debauched" (Chekhov 2004, letter to Suvorin, 204-205). Like many writers of the time, Chekhov's conscience was more exercised by the persecution of his fellow Russians than by the extermination of the Gilyak. Finally, and perhaps most importantly, whereas the Gilyak 
were rapidly approaching extinction in the first decade of the 20th century, the Maori were not so close to the brink of extinction during Chekhov's and Mansfield's lifetimes.

Mansfield did not read Chekhov's book on Sakhalin, one of his most neglected works. The first translation of Sakhalin appeared in German eight years after Mansfield's death (Chekhov 1931). Perhaps due to its Asian setting, Sakhalin was next translated into Japanese and subsequently Chinese and Korean. The first translation of the text into English, The Island: A Journey to Sakhalin appeared in 1967 (Chekhov 1967) and the first French translation appeared only four years later (Chekhov 1971). In short, although Mansfield co-translated Russian literary classics (Davison 2014), and letters by Chekhov (McDonnell 2010, 177), she never read Chekhov's account of his voyage to the Far Eastern island. The comparison assayed here is thus one of confluence rather than influence.

Notwithstanding the lack of direct influence, the resemblances between Chekhov's and Mansfield's depictions of the colonial situation are striking. While critical of settler colonialism inasmuch as it was premised on the extermination of the native population, and keeping their distance from the colonial class to which they belonged, both writers avoided subsuming aesthetics into polemics. Their reticence did not stem from apathy or indifference to the consequences of settler colonialism. Rather, both writers were instinctively persuaded that mere polemics could not intervene in, or halt, the process they were witnessing. In using settler colonial aesthetics to come to terms with their own mortality and with the mortality of the indigenous peoples they were describing, they revealed how art, sometimes silently but nearly always unexpectedly, bears witness to political catastrophe.

\section{Colonization as destiny}

Chekhov's ethnography of the Gilyak internalizes key tenets of the settler colonial enterprise while also seeking to reform them in more liberal directions. In Chekhov's salvage anthropology, the vulnerability to extinction of the ethnographic group in question is assumed (Veracini 2011a, 4). Specific features of their culture and way of life are recorded in writing to provide what Chekhov calls "indications that will be useful in practice for new colonisers [novichkov-kolonistov]" (Chekhov 2010, 131). As these words suggest, Chekhov's representations of the Gilyak are fraught with ambivalence. Whereas Mansfield's representations of the Maori appear fraught with anxiety, perhaps due to the fate awaiting them, Chekhov's representations evoke nostalgia. They are not the "fiercest words [ ... ] against the/colonial violence of the convict settlers" that American poet Ed Sanders (1995, 129-130) claimed them to be in his rhapsody-in-verse to Chekhov.

Far from producing a polemic against colonization, Chekhov produced a text that made colonization palatable, and that assisted doctors "in learning the conditions under which our [Russian] interference in the life of the [Gilyak] people could bring them the least harm" (Chekhov 2010, 133). Whether such a work is read as an apology for empire, or as an attempt to mitigate the harms of conquest, it would be a mistake to position it entirely in opposition to the settler colonial process. Chekhov's work is situated at the juncture where salvage ethnography compensates for the loss of a way of life through scientific inquiry. Even as the natives perish, the memory of them lingers. Literature, along with other forms of artistic expression, is instrumental to this memorialization. 
Chekhov assumed the inevitability of colonialization. Gilyaks, in his view, were destined for annihilation. "It is not within medicine's power to arrest fatal extinction", he wrote bleakly (Chekhov 2010, 133). Yet he did seek to improve on existing forms of colonization. Hence, Chekhov cautiously objected to a general's plan to Russify the Sakhalin Gilyaks, noting "I do not see why this should be necessary" (136). Chekhov concluded his chapter on the Gilyak (which opens with the probing question, "Was their colonization done in freedom?") by suggesting mildly, "if Russification is inevitable [ ... ] it should be done by taking their needs, rather than ours, into consideration" (137). With these words, Chekhov develops an anti-colonial aesthetic and a counterimperial politics in the making. He also demonstrates awareness that the best interests of the native population do not necessarily coincide with the best interests of the colonizing power. Yet the precise fault lines of these differences remain unarticulated within Chekhov's work.

Chekhov goes on to praise recent governmental policies that allowed the Gilyak to receive treatment at the local hospital, to receive food rations, to protect their possessions from confiscation and to have their debts forgiven. He advocates in short for a humane colonialism, not for the abolition of the settler colonial project, except insofar as this might be an unintended outcome of his primary object of critique: the Russian penal system. It might be said in Chekhov's defence that he was seeking to achieve the best possible outcome for the Gilyak against difficult odds, and under the aegis of a government that would not limit its imperial ambitions, or allow freedom of the press to generate a meaningful anti-imperial critique. A call to cease colonizing Siberia would have had little traction within Russian society of the time. Read within the context of the colonial discourse that dominated Chekhov's intellectual milieu, wherein entire ethnic groups (especially in the Caucasus) were regularly and systematically expelled from their homelands, Chekhov's account of the decimation of the Gilyak reads like a progressive, if state-centric and ultimately pro-colonial, intervention. ${ }^{8}$

Couched in terms of progressive liberalism, Chekhov's attitude epitomizes key aspects of the settler colonial project, from Russia to Australia to the Americas. Within settler colonialism, Wolfe clarifies, the "primary object" is "the land itself rather than the surplus value to be derived from mixing native labour with it" (Wolfe 1999, 163). Colonialism as practised across South Asia and throughout much of Africa involved governing a non-contiguous region from afar and with the assistance of natives who were willing to implement colonial law and to keep colonial institutions afloat. It aimed at the extraction of labour and resources rather than accupation and extinction. By contrast, the settler colonialism that was operative in Siberia, the Russian Far East, and the penal colonies wherein the settler population replaced the native population did not require the natives in order to administer its laws. In terms of constituting a modern state, settler colonialism prefers the native's (gradual) disappearance.

Every paradigm must be viewed in light of the cases it proposes to explain. The Russian Empire diverges from the classical settler colonial paradigm set forth by Wolfe and Veracini in that it borrowed many strategies from the imperial colonial repertoire. Many types of colonialism coexisted under its aegis, including hierarchies organized around "religious belief, but not on race or the degree of admixture of 'European' blood, as was common in many other colonial or creole societies" (Morrison 2017, 315) 
formed by anglophone, francophone and hispanophone settler colonialism. ${ }^{9}$ According to Morrison, only with the creation of the Resettlement Administration in 1896 did Russia witness the "beginning of a systematic, technocratic, state-driven policy of exporting peasants from the crowded Central Agricultural and Black Earth regions of European Russia to Siberia, the Asiatic Steppe and Turkestan" (316). Equally, the substantial differences between modes of exercising sovereignty over the indigenous population in the case of New Zealand, which had Maori members of parliament in the early 20th century (Bargh 2010), and Australia, which did not grant citizenship to Aborigines and Torres Strait islanders or include them within its census until the late 1960s, merit thoroughgoing disambiguation.

Annihilation of the native population, whether through disease, genocide or a combination of both, is the endpoint of the settler colonial process as it functioned in the early 20th century. Ethnography undertaken from this point of view memorializes in an effort to preserve, as if in a museum, the ways of life of peoples threatened by extinction. The Gilyaks' Russification meant their eventual extermination, albeit at a pace that enabled the process to appear like a gentle act of salvation rather than outright genocide. While figuring his approach to colonialism as that of the well-intentioned doctor, Chekhov also eulogized the slow violence of the settler colonial enterprise. Mansfield inherited Chekhov's ambivalence towards colonialism, while depicting its violence with greater cognitive dissonance. Like Chekhov, however, she could not oppose it wholeheartedly, or in a polemical mode. Both writers were torn between their perception of the superiority of European culture and their first-hand observation of the brutality of the colonizing process.

\section{The colonial subconscious}

As Chekhov had done with his book on Sakhalin, Mansfield used her trip to assemble material for later writing projects. Although she never envisioned its publication, Mansfield took the notebook with her when she moved to London, and quoted from it in subsequent years when seeking inspiration for new stories. In labelling Sakhalin the place where Asia ends, Chekhov initiated what anthropologist Bruce Grant (Shternberg, [1993] 1999, xxx) calls "a tradition of prosaic exaggeration about the island's isolation", that failed to acknowledge its proximity to major Russian cities such as Vladivostok (a city with a population of 28,896 in 1897 according to the Russian Imperial Census). ${ }^{10}$ Much as Sakhalin marked the end of the known world for Chekhov, the more proximate and accessible Ureweras signified for Mansfield a space alien to the anglophone imagination. In the words of Mansfield's biographer, Claire Tomalin (1988), New Zealand was "the very last place, the furthest you could go, the end of the line" (8). What Sakhalin was to Siberia, New Zealand was to Australia: a colonial "margin of empire in the most extreme sense" of the term (Majumdar 2013, 75).

And yet Mansfield negotiated this imperial margin in ways quite different from Chekhov. Whereas Chekhov drew on his medical training, statistics and prior ethnography to evoke the Gilyak world, Mansfield's cinematographic rendering of the Maori juxtaposes images and impressions without attempting a synthesis. The scenes she encountered in her three-week journey and evoked in her notebook were to inspire some of Mansfield's most memorable short stories, from "The Woman at the Store" (1912) to "Millie" (1913). 
Whereas Chekhov scientifically objectified the Gilyak, Mansfield emotionally internalized the Maori she encountered on her journey through the Ureweras.

Midway through her journey, Mansfield records a dream that awakens her in the middle of the night: "Round us in the dark-ness the horses were moving softly - with a most eerie sound - visions of long dead Maoris - of forgotten battles and vanished feuds - stirred in me" $(2015,89)$. When she awakens from her dream, Mansfield encounters

a little Maori whare [carved meeting house - RG] [ ... ] painted black against the wide sky. Before it - two cabbage trees stretched out phantom fingers - and a dog, watching me coming up the hill, barked madly - Then I saw the first star - very sweet \& faint - in the yellow sky - and then another \& another - like holes. (89)

The slippage between animacy and inanimacy (for example, "it") suggests in this context the author's apprehension that the objects in her natural surroundings will suddenly spring to life and call her to account for the destruction underway. Similarly, the phantom fingers and the barking dog indicate a premonition of guilt, or at least of impending disaster.

Another later passage describes the scene of the massacre of Opipi (1869), where nine New Zealand soldiers were killed by Maori fighting for Te Kooti (Binney 2009, 209-211). Many sections of Mansfield's notebook entries are written like prose poems, and hence must be absorbed as single units, with all their orthographic irregularities intact:

We wake early - and wash and dress - \& go down to the bath again - Honeysuckle - roses pink and white - periwinkles syringas - red hot pokers - those yellow flowers - the ground is smothered - Fruit trees with promise of harvest - the hot lakes \& pools - even - the homely clothes prop in the lush grass - \& more mimosa - the birds are magical - I feel I cannot leave but pluck the honeysuckle \& the splashes of light lie in the pine wood - Then good bye Taupo and here are more plains I feel quite at home again - \& at last we come to Opipi - the scene of a most horrible massacre - only 2 men were saved - one rushed through the bush - one was cutting wood - we stop to look for water and there are two men - one [illegible] one most perfect Maori - like bronze the new pink shirt printed images - his horrible licensed walk his cigarette - Then we are in a valley of broom - such color - it is strewn everywhere. $(2015,108)$

The expository style of this passage exposes the process through which how these events are absorbed into settler colonial consciousness. As throughout the notebook, Mansfield does not use periods, commas or other conventional punctuation marks. Instead, she relies almost entirely on dashes to convey the flow of the syntax. Her images are cinematic in their impact. They do not aim at acclimatizing the reader to the environment but seek rather to induce a shock effect. The use of tense is also noteworthy; all events in Mansfield's notebook are narrated in the present tense. When the Maori man emerges on the scene, the reader cannot but link him to the fighters for Te Kooti who defeated the New Zealand soldiers a few decades earlier.

As Plumridge notes, Mansfield later used the scene at Opipi in her 1909 poem "In the Rangitaiki Valley" (see Mansfield 2016, 50-51, 155; 2015, 108, note to line 664). The following notebook entry evokes the scene that was to provide the setting for a story composed five years later in 1912, "The Woman at the Store", which is remembered for its surreptitious depiction of colonial violence. This passage too must be absorbed in full in order to grasp its lineage within the surreal yet compelling description of the massacre: 
I have never dreamed of such vivid blossom - Then lunch at Rangiteiki, the store is so ugly - they do not seem glad or surprised to see us - give us fresh bread, all seems so familiar, and they seem [? troubled] - And afar the plain - We say goodbye to [illegible] - and at night fall rounding the road, reach our copse. It is a threatening evening - the farm child the woman her great boots - she has been digging - How glad she is to see us - her garrulous ways and the children's thoughtful fascination Then at night among the tussocks Then the pumice hills - river - and rain pours - . (Mansfield 2015, 109)

The "blossom" referenced in this passage is taken from Mansfield's dream in the prior notebook entry. Yet the scene rapidly shifts to a daylight hour, dominated by lunch at Rangitaiki. The contrast between the sublimity of the natural environment and the dilapidation of settler life is striking. Everyone's countenance is shot through either with fear or exhaustion. The slippages in the above passages between the terror of the night and the surreal impossibility of the day, and between a hostile nature and a nature that beckons and enfolds, are expressed in Mansfield's disjointed parataxis. As Majumdar notes, Mansfield's “awareness of a traumatic colonial history rooted in the same landscape that served as the setting of the story clearly influenced her depiction of what is one of the bleakest, bitterest, and darkest ambiences in her work" $(2013,94)$. The juxtaposition of the Opipi massacre with the vertiginous tableau of the Rangitaiki Valley reveals how "ravaged indigenous landscapes and histories get metonymically transformed in Mansfield's imagination" as "violence, bitterness, and trauma" are "divested of their mooring in indigenous history" (94). Mansfield goes a step further than Chekhov in aesthetically disentangling the settler colonial project and in acknowledging the injustices it perpetuated, but even her cinematographic juxtapositions participate in the discourse of salvage anthropology that was coeval with the political project of settler colonialism.

In this article, I have argued against the nascent tendency, evident within some strands of anglophone postcolonial studies, to neatly enfold colonial-era modernist writers within an anti-colonial project, as if their aims and agendas were entirely convergent. Such a seamless merger of these varying intellectual agendas works against an accurate assessment of their work, and ignores the radical disjuncture between the colonial readership of Chekhov and Mansfield on the one hand, and of anti-colonial and postcolonial writing on the other. Only when indigenous authors begin to read - and to write - the texts that memorialize their violent colonization can settler colonialism be rigorously scrutinized. What is needed is not just opposition to colonial violence, but a new way of understanding the imbrication of colonial aesthetics within colonial politics. Theoretical engagements with the settler colonial paradigm can help us access these ways of seeing, but without indigenous voices our angles of vision will always be incomplete.

Notwithstanding their liberal ambivalence towards the state-sanctioned destruction of native peoples, both Chekhov and Mansfield contributed to the very discourse that normalised these atrocities. At the same time, these writers were not mere servants of empire. They infused into their complicit texts counter-discourses that undid much, if not all, of settler colonial logic. With regard to Chekhov's book on Sakhalin, Popkin (1992) argues that the work that "begins by fixing the longitudinal coordinates ends with an extreme sense of dislocation" (38). By deploying discontinuous narrative, irony and cinematographic modes of representation, rather than outright denunciation within their literary texts, both 
Chekhov and Mansfield cast doubt on the integrity of the colonial mission, and reminded their readers of what many of them may have wished to forget: that their own prosperity was directly enabled by the conquest of other peoples.

\section{Notes}

1. The title "Urewera Notebook" was bestowed on the text by Ian Gordon, as Mansfield did not name her notebooks.

2. This recent critical edition represents a significant advance in terms of philological and paleographic precision over Gordon's edition (Mansfield 1978). As Plumridge notes (Mansfield 2015, 43), "phrases introduced by Mansfield above or below the line have been inserted into the sentence $[\ldots]$ and are indicated by caret marks $[\wedge]$ ". This applies to passages quoted in this article.

3. Census data is available at http://www.gks.ru/free_doc/new_site/perepis2010/croc/pere pis_itogil612.htm.

4. It is telling that one of the most important discussions of Chekhov's ethnography is by an anthropologist rather than a literary critic. See Narayan (2012).

5. The field of Russophone postcolonial and anti-colonial studies is in its extreme infancy. There is more work on the Soviet and post-Soviet period, such as Uffelmann and Smola (2016). For anti-colonial literature in the early years of the Soviet Union, see Gould (2016).

6. The French title, Israel, fait colonial, does not make the link with settler colonialism as explicit as does the English translation; nonetheless, even without being named, this paradigm is implicit within Rodinson's argument.

7. Another useful definition of settler colonialism is offered by the editors of Settler Colonial Studies, who note that "settler colonialism is not colonialism: settlers want Indigenous people to vanish. [ ... ] Sometimes settler colonial forms operate within colonial ones, sometimes they subvert them, sometimes they replace them. But even if colonialism and settler colonialism interpenetrate and overlap, they remain separate as they co-define each other" (Cavanagh and Veracini 2013, 1). "Settler colonialism" has as yet no entry in the Oxford English Dictionary.

8. For the expulsion of ethnic groups from their homelands, see the account by Richmond (2013) of the colonization.

9. Many scholars, including Bassin (1999), Crews (2006), Morrison (2008) and Sunderland (2016), have weighed in on the issue of the paradigm to which the Russian Empire corresponds, without specifically engaging with the settler colonial paradigm. This paradigm is also ignored by the new generation of scholarship surveyed in Morrison (2016), even when this new scholarship deals extensively with non-Russian sources and perspectives. See, however, Morrison (2017) for a groundbreaking discussion of this topic in relation to Russian history.

10. Russian Imperial Census figures are found in Pervaia Vseobshhaia perepis' naseleniia Rossiiskoi Imperii $1897 \mathrm{~g}$. Tablitsa XIII. Raspredelenie naseleniia po rodnomu iazyku [The First General Census of the Russian Empire of 1897. Table XIII. Breakdown of Population by Mother Tongue]. Vols 1-50. Saint-Petersburg, 1903-05 (http://demoscope.ru/weekly/ ssp/rus_lan_97_uezd_eng.php).

\section{Disclosure statement}

No potential conflict of interest was reported by the author. 


\section{Funding}

This publication has received funding from the European Union's Horizon 2020 Research and Innovation Programme under ERC-2017-STG Grant Agreement No 759346.

\section{Notes on contributor}

Rebecca Ruth Gould directs the European Research Council-funded "Global Literary Theory" project at the University of Birmingham, where she is professor, Islamic world and comparative literature. She is the author of Writers and Rebels: The Literature of Insurgency in the Caucasus (2016) which was awarded the University of Southern California Book Prize in Literary and Cultural Studies and the best book award by the Association for Women in Slavic Studies, and translator of Prose of the Mountains (2015), and After Tomorrow the Days Disappear: Poems of Hasan Sijzi of Delhi (2015).

\section{ORCID}

Rebecca Ruth Gould (D) http://orcid.org/0000-0002-2198-5406

\section{References}

Ahmad, Aijaz. 1992. In Theory: Classes, Nations, Literatures. London: Verso.

Aretoulakis, Emmanouil. 2013. "Colonialism and the Need for Impurity: Katherine Mansfield, 'The Garden Party' and Postcolonial Feeling." In Katherine Mansfield and the (Post)Colonial, edited by Janet M Wilson, Gerri Kimber, and Delia de Sousa Correa, 45-62. Edinburgh: Edinburgh University Press.

Bargh, Maria. 2010. Māori and Parliament: Diverse Strategies and Compromises. Wellington: Huia.

Bassin, Mark. 1999. Imperial Visions: Nationalist Imagination and Geographical Expansion in the Russian Far East, 1840-1865. Cambridge: Cambridge University Press.

Beer, Daniel. 2016. "Sakhalin." In The House of the Dead: Siberian Exile under the Tsars. London: Allen Lane.

Binney, Judith. 2009. Encircled Lands: Te Urewera, 18201921. Wellington: Bridget Williams Books.

Boehmer, Elleke. 2011. "Katherine Mansfield as Colonial Modernist." In Celebrating Katherine Mansfield: A Centenary Volume of Essays, edited by Gerri Kimber and Janet Wilson, 57-71. Basingstoke: Palgrave.

Cavanagh, Edward, and Lorenzo Veracini. 2013. “Editor's Statement." Settler Colonial Studies 3 (1): 1. doi:10.1080/18380743.2013.768169.

Chekhov, Anton Pavlovich. 1931. Sachalin, Russlands schreckensinsel. Translated into German by Alexander von der Ley. München: Münchener Druck- und Verlagshaus GmbH.

Chekhov, Anton Pavlovich. 1967. The Island: A Journey to Sakhalin. Translated by Luba and Michael Terpak. New York: Washington Square Press.

Chekhov, Anton Pavlovich. 1971. L'ile de Sakhaline : notes de voyage, translated Lily Denis. Paris: Éditions Les Éditeurs Français Réunis.

Chekhov, Anton Pavlovich. 2004. A Life in Letters, edited by Rosamund Bartlett. Translated by Anthony Phillips, New York: Penguin.

Chekhov, Anton Pavlovich. 2010. Ostrov Sakhalin: Iz Putevykh Zapisok [Sakhalin Island: From Travel Notes], edited by M. Vysokov. Vladivostok and Sakhalin: Rubezh.

Colonisation in South Australia and New Zealand. 1838 The Phrenological Journal and Magazine of Moral Science 11: 247-259. 
Crews, Robert. 2006. Prophet and Tsar: Islam and Empire in Russia and Central Asia. Cambridge, MA: Harvard University Press.

Davison, Claire. 2014. Translation as Collaboration: Virginia Woolf, Katherine Mansfield and S. S. Koteliansky. Edinburgh: Edinburgh University Press. doi:10.3366/edinburgh/ 9780748682812.001.0001.

Doroshevich, Vlas Mikhailovich. [1905] 2009. Russia's Penal Colony in the Far East: A Translation of Vlas Doroshevich's "Sakhalin". Translated by Andrew A. Gentes. London: Anthem Press.

Dutt, Bishnupriya. 2013. "Theatre and Subaltern Histories: Chekhov Adaptation in PostColonial India." In Adapting Chekhov: The Text and Its Mutations, edited by J. Douglas Clayton and Yana Meerzon, 145-160. London: Routledge.

Glissant, Édouard. 1997. Poetics of Relation. Translated by Betsy Wing. Minneapolis, MN: University of Minnesota Press.

Gordon, Ian. 1993. "Introduction: Katherine Mansfield: The Wellington Years: A Reassessment." In Critical Essays on Katherine Mansfield, edited by Rhoda B Nathan, 61-74. Boston, MA: G.K. Hall.Translated by S. S. Koteliansky and Leonard Woolf

Gould, Rebecca. 2016. Writers and Rebels: The Literature of Insurgency in the Caucasus. New Haven, CT and London: Yale University Press.

Grant, Bruce. 1995. In Soviet House of Culture: A Century of Perestroikas. Princeton, NJ: Princeton University Press.

Grant, Bruce. 1997. “The Politics of Primitivism in Late Imperial Russia.” In Russia's Orient: Imperial Borderlands and Peoples, 1700-1917, edited by Daniel R. Brower and Edward J. Lazzerini, 292-310. Bloomington, IN: Indiana University Press.

Ihimaera, Witi. 1989. Dear Miss Mansfield: A Tribute to Kathleen Mansfield Beauchamp. New York: Viking.

Jackson, Penelope. 2010. "Double Portrait: Katherine Mansfield and S. S. Koteliansky in the Garden.” Katherine Mansfield Studies 2: 188-195. doi:10.3366/kms.2010.0014.

Labbé, Paul. 1903. Ostrov Sakhalin: Putevye Vpechatlieniia [The Island of Sakhalin: Travel Impressions, translated into Russian by N. Vasin. Moscow: M. Kliukin.

Lantz, Victoria Petterson. 2013. "What Comes 'After Chekhov'? Mustapha Matura and West Indian Reiterations of Three Sisters." In Adapting Chekhov: The Text and Its Mutations, edited by J. Douglas Clayton and Yana Meerzon, 161-179. London: Routledge.

Majumdar, Saikat. 2013. Prose of the World: Modernism and the Banality of Empire. New York: Columbia University Press.

Mansfield, Katherine. 1946. The Journal of Katherine Mansfield, edited by John Middleton Murry. New York: Knopf.

Mansfield, Katherine. 1951. Letters of Katherine Mansfield to John Middleton Murry 1913-1922, edited by J. Middleton Murry. Constable: London.

Mansfield, Katherine. 1978. The Urewera Notebook, edited by Ian Gordon. Oxford: Oxford University Press.

Mansfield, Katherine. 2015. The Urewera Notebook by Katherine Mansfield, edited by Anna Plumridge. Edinburgh: Edinburgh University Press.

Mansfield, Katherine. 2016. The Collected Poems of Katherine Mansfield, edited by Gerri Kimber and Claire Davison. Edinburgh: Edinburgh University Press.

McDonnell, Jenny. 2010. Katherine Mansfield and the Modernist Marketplace: At the Mercy of the Public. New York: Springer.

Morrison, Alexander. 2008. Russian Rule in Samarkand 18681910: A Comparison with British India. Oxford: Oxford University Press.

Morrison, Alexander. 2016. "Muslims and Modernity in the Russian Empire." The Slavonic and East European Review 94 (4): 715-724. doi:10.5699/slaveasteurorev2.94.4.0715.

Morrison, Alexander. 2017. “The Routledge Handbook of the History of Settler Colonialism.” In Russian Settler Colonialism, edited by Lorenzo Veracini and Ed Cavanagh, 313-326. Abingdon: Routledge. 
Narayan, Kirin. 2012. Alive in the Writing: Crafting Ethnography in the Company of Chekhov. Chicago: University of Chicago Press.

Nurse, Andrew. 2011. "Marius Barbeau and the Methodology of Salvage Ethnography in Canada, 1911-1951." In Historicizing Canadian Anthropology, edited by Julia Harrison and Regna Darnell, 52-64. Vancouver: University of British Columbia Press.

Orr, Bridget. 1995. “The Maori House of Fiction.” In Cultural Institutions of the Novel, edited by Deidre Lynch and William Beattie Warner, 73-95. Durham, NC: Duke University Press.

Popkin, Cathy. 1992. "Chekhov as Ethnographer: Epistemological Crisis on Sakhalin Island." Slavic Review 51 (1): 36-51. doi:10.2307/2500260.

Rayfield, Donald. 1997. Anton Chekhov: A Life. London: Harper Collins.

Richmond, Walter. 2013. The Circassian Genocide. Rutgers, NJ: Rutgers University Press.

Rodinson, Maxime. [1968] 1973. Israel: A Colonial-Settler State? Translated by David Thorstad. Atlanta, GA: Pathfinder Press.

Said, Edward. 1978. Orientalism. New York: Vintage Books.

Said, Edward. 1993. Culture and Imperialism. New York: Vintage Books.

Sanders, Ed. 1995. Chekhov. Boston, MA: David R. Godine.

Shalhoub-Kevorkian, Nadera. 2016. "The Occupation Of The Senses: The Prosthetic and Aesthetic Of State Terror" The British Journal of Criminology 57 (6): 1279-1300. doi:10.1093/bjc/azw066.

Shternberg, Lev. [1933] 1999. The Social Organization of the Gilya. [Giliaki, Orochi, Gol'dy, Negidal'tsy, Ainy]. Translated by Bruce Grant. New York and Seattle, WA: American Museum of Natural History and the University of Washington Press.

Sunderland, Willard. 2016. Taming the Wild Field: Colonization and Empire on the Russian Steppe. Ithaca, NY: Cornell University Press.

Tomalin, Claire. 1988. Katherine Mansfield: A Secret Life. New York: Knopf.

Uffelmann, Dirk, and Klavdia Smola, eds. 2016. Postcolonial Slavic Literatures after Communism. Frankfurt: Peter Lang.

Veracini, Lorenzo. 2011a. "Introducing Settler Colonial Studies." Settler Colonial Studies 1 (1): 112. doi:10.1080/2201473X.2011.10648799.

Veracini, Lorenzo. 2011b. “On Settlerness.” Borderlands E-Journal 10 (1): 1-17.

Williams, Mark. 2000. "Mansfield in Maoriland: Biculturalism, Agency, and Misreading." In Modernism and Empire, edited by Howard J Booth and Nigel Rigby, 249-274. Manchester: Manchester University Press.

Wilson, J.M., Gerri Kimber, and Delia de Sousa Correa, eds. 2013. Katherine Mansfield and the (Post)Colonial. Edinburgh: Edinburgh University Press.

Wilson, Janet. 2013. Introduction to Katherine Mansfield and the (Post)Colonial, edited by Janet Wilson, Gerri Kimber, and Delia de Sousa Correa, 1-11. Edinburgh: Edinburgh University Press.

Wolfe, Patrick. 1999. Settler Colonialism and the Transformation of Anthropology. London: Cassell.

Wolfe, Patrick. 2006. "Settler Colonialism and the Elimination of the Native." Journal of Genocide Research 8 (4): 387-409. doi:10.1080/14623520601056240. 